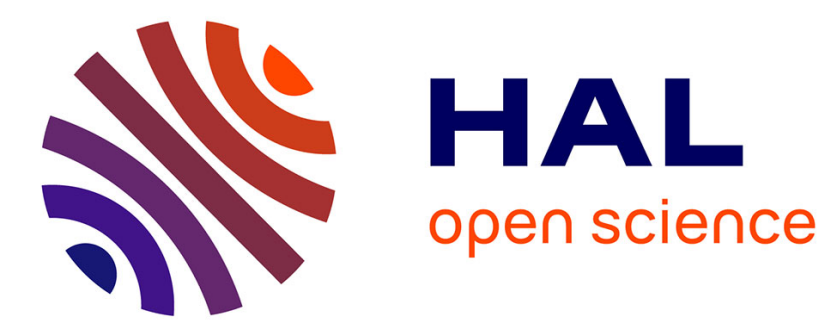

\title{
Ultradispersed $\mathrm{Mo} / \mathrm{TiO} 2$ catalysts for $\mathrm{CO} 2$ hydrogenation to methanol
}

\author{
T. Len, M. Bahri, O. Ersen, Y. Lefkir, L. Cardenas, I. Villar-Garcia, V. \\ Dieste, J. Llorca, N. Perret, E. Puzenat, et al.
}

\section{- To cite this version:}

T. Len, M. Bahri, O. Ersen, Y. Lefkir, L. Cardenas, et al.. Ultradispersed Mo/TiO2 catalysts for CO2 hydrogenation to methanol. Green Chemistry, 2021, 23, pp.7259-7268. 10.1039/d1gc01761f . hal-03339757

\section{HAL Id: hal-03339757 https://hal.science/hal-03339757}

Submitted on 28 Sep 2021

HAL is a multi-disciplinary open access archive for the deposit and dissemination of scientific research documents, whether they are published or not. The documents may come from teaching and research institutions in France or abroad, or from public or private research centers.
L'archive ouverte pluridisciplinaire HAL, est destinée au dépôt et à la diffusion de documents scientifiques de niveau recherche, publiés ou non, émanant des établissements d'enseignement et de recherche français ou étrangers, des laboratoires publics ou privés. 


\section{Ultradispersed $\mathrm{Mo} / \mathrm{TiO}_{2}$ catalysts for $\mathrm{CO}_{2}$ hydrogenation to methanol}

Thomas Lena, Mounib Bahrib, Ovidiu Ersen ${ }^{\text {b }}$, Yaya Lefkirc, Luis Cardenasa ${ }^{a}$, Ignacio J. Villar-Garciad, Virginia Pérez Dieste ${ }^{\mathrm{d}}$, Jordi Llorcae, Noémie Perreta ${ }^{\mathrm{a}}$, Ruben Checaa ${ }^{\mathrm{a}}$ Eric Puzenat, ${ }^{\text {a Pavel Afanasieva }}$, Franck Morfin and Laurent Piccolo ${ }^{\mathrm{a}^{*}}$

a Univ Lyon, Université Claude Bernard Lyon 1, CNRS, IRCELYON, F-69626 Villeurbanne, France

${ }^{b}$ Institut de Physique et Chimie des Matériaux de Strasbourg (IPCMS), UMR 7504, CNRS-Université de Strasbourg, 23 rue du Lœss, 67034 Strasbourg Cedex 2, France

${ }^{c}$ Laboratoire Hubert Curien, UMR 5516, 42000 Saint-Etienne, France

${ }^{d}$ ALBA Synchrotron Light Source, Carrer de la Llum 2-26, 08290 Cerdanyola del Vallès, Barcelona, Spain

${ }^{e}$ Institute of Energy Technologies, Department of Chemical Engineering and Barcelona Research Center in Multiscale Science and Engineering, Universitat Politècnica de Catalunya, EEBE, Eduard Maristany 16, 08019 Barcelona, Spain

*Corresponding author: laurent.piccolo@ircelyon.univ-lyon1.fr 


\section{Abstract}

$\mathrm{Mo} / \mathrm{TiO}_{2}$ catalysts with atomic dispersion of molybdenum appear active and stable in the gas-phase hydrogenation of $\mathrm{CO}_{2}$. The comparison between various titania materials shows a crucial effect of the support surface structure on the methanol yield. Molybdenum supported at low coverage on rutile titania nanorods is the most active and methanol-selective system. From catalyst characterization by aberration-corrected scanning transmission electron microscopy, near-ambient pressure X-ray photoelectron spectroscopy, diffuse reflectance UVvis spectroscopy, and temperature-programmed techniques, we suggest that the most active catalysts for methanol production involve atomically-dispersed oxomolybdate species with high reducibility and strong interaction with the rutile support.

\section{Introduction}

Due to environmental concerns, and following the European Commission climate strategies and targets, ${ }^{1}$ the reduction of greenhouse gas emissions has become mandatory. In this context, promising approaches for the valorisation of $\mathrm{CO}_{2}$ have been developed, allowing the synthesis of value-added chemicals such as urea, salicylic acid, cyclic carbonate and polypropylene carbonate at the laboratory scale. ${ }^{2-4}$ The most promising valorisation strategyprovided that electricity and hydrogen production costs are reduced ${ }^{5,6}$ - consists in the transformation of effluent $\mathrm{CO}_{2}$ through catalytic hydrogenation, ${ }^{7-10}$ leading to valuable products such as carbon monoxide, hydrocarbons and oxygenates. ${ }^{11,12}$ Methanol, a platform chemical with high interest in the production of fuels and plastics, ${ }^{13,14}$ is industrially produced from syngas $\left(\mathrm{CO}\right.$ and $\mathrm{H}_{2}$ ) in the presence of a $\mathrm{Cu} / \mathrm{ZnO} / \mathrm{Al}_{2} \mathrm{O}_{3}$ catalyst at 5-10 MPa and 250-300 ${ }^{\circ} \mathrm{C}$. Researches on $\mathrm{CO}_{2}$ hydrogenation to methanol have mostly focused on this system, for understanding and optimising its catalytic performances. ${ }^{15-21}$ However, this catalyst is pyrophoric, and a serious threat exists in the next decades for zinc availability. ${ }^{22}$ Moreover, the 
generation of water as a by-product of $\mathrm{CO}_{2}$ hydrogenation induces $\mathrm{ZnO}$ agglomeration, $\mathrm{Cu}$ oxidation and sintering, leading to catalyst deactivation..$^{23,24}$ Hence, it is desirable to find alternative catalysts with enhanced performances. ${ }^{25-27}$ This includes not only the catalyst stability but also its activity and selectivity to methanol. ${ }^{28}$

Ultradispersed metal-based catalysts, i.e. single-atom catalysts (SACs) or subnanometric cluster-based catalysts, ${ }^{29}$ are an attractive new class of materials which potentially offer maximum atom-efficiency and specific catalytic properties. ${ }^{30-33} \mathrm{~A}$ large fraction of SAC studies has focused on noble metals, with a view to cost reduction. Although some strategies have been proposed, ${ }^{34-37}$ the stabilization of single noble-metal atoms on oxides is challenging because of their tendency to aggregation. ${ }^{29,38-40}$

Molybdenum-based catalysts are widely used in petroleum refining, and catalyze syngas conversion to alcohols. ${ }^{41}$ Mo has a half-filled d-electron shell and a variable valence state, which makes this oxophillic element suitable for tuning the catalytic performance through coordination engineering. ${ }^{42}$ Non-precious catalysts containing Mo-based species supported on $\mathrm{TiO}_{2}\left(\mathrm{MoO}_{x} / \mathrm{TiO}_{2}, \mathrm{MoS}_{2} / \mathrm{TiO}_{2}\right.$, etc. $)$ are well-known for photocatalysis, ${ }^{43}$ as well as thermocatalytic oxidation $\mathrm{n}^{44,45}$ and hydrodesulfurization ${ }^{46-48}$ reactions. When $\mathrm{CO}$ and $\mathrm{CO}_{2}$ hydrogenation reactions were carried out over $\mathrm{Mo} / \mathrm{TiO}_{2},{ }^{49-51}$ this system was found inefficient. Shimizu's group recently reported that the addition of a noble metal such as Pt is mandatory to activate a $30 \mathrm{wt} \% \mathrm{Mo} / \mathrm{TiO}_{2}-\mathrm{P} 25$ sample for the $\mathrm{CO}_{2}$-to-methanol reaction. ${ }^{51}$

Herein, we disclose the unexpected $\mathrm{CO}_{2}$ hydrogenation performances of selected low wt\% $\mathrm{Mo} / \mathrm{TiO}_{2}$ catalysts. A broad range of $\mathrm{TiO}_{2}$ materials, $\mathrm{Mo}$ loadings and pretreatment conditions were studied to compare their impacts on $\mathrm{CO}_{2}$ conversion activity and selectivity to methanol.

\section{Experimental section}

\section{Catalyst preparation}


The $\mathrm{TiO}_{2}$ samples, the molybdenum precursor (Aldrich, 99.98\% trace metals basis) and the reference $\mathrm{Cu} / \mathrm{ZnO} / \mathrm{Al}_{2} \mathrm{O}_{3}$ catalyst (Thermo Fisher) were used without specific treatment. For titania supports, DT51D (>99.5\%) and PC500 (>85\%) were obtained from Tronox, P25 and P90 (>99.5\%) were purchased from Evonik Aeroxide, and RL11A (>99.5\%) was purchased from Solvay.

In a typical preparation, $5 \mathrm{~g}$ of $\mathrm{TiO}_{2}$, an appropriate amount (depending on the target $\mathrm{Mo}$ loading) of $\mathrm{Mo}_{7} \mathrm{O}_{24}\left(\mathrm{NH}_{4}\right)_{6} \cdot 4 \mathrm{H}_{2} \mathrm{O}$ and $60 \mathrm{~mL}$ of deionized water were stirred for $2 \mathrm{~h}$ in a round bottom flask. The mixture was dried in a rotary evaporator at $60{ }^{\circ} \mathrm{C}$, and the resulting powder was treated in a flow fixed-bed reactor under $\mathrm{H}_{2}(40 \mathrm{~mL} / \mathrm{min})$ for $2 \mathrm{~h}$ at $500{ }^{\circ} \mathrm{C}\left(5^{\circ} \mathrm{C} / \mathrm{min}\right)$.

\section{Catalytic testing}

The catalytic tests were performed using a straight stainless-steel flow fixed bed reactor (internal diameter $7 \mathrm{~mm}$ ), heated with a tubular oven. Gas flows were controlled by Brooks Instruments flowmeters and analyzed by an Inficon Fusion micro gas chromatograph equipped with molecular sieve and RT-Q-Bond modules. The temperature program for the RT-Q-Bond was $60{ }^{\circ} \mathrm{C}$ for $70 \mathrm{~s}$, then $230^{\circ} \mathrm{C}$ for $120 \mathrm{~s}\left(2.5^{\circ} \mathrm{C} / \mathrm{min}\right)$. The total pressure was set to 30 bar using a Tescom ER5000 electropneumatic PID controller driving a Tescom membrane backpressure regulator. A heating system was set up to keep the temperature above $70^{\circ} \mathrm{C}$ in the gas lines in order to avoid condensation. Prior to catalytic tests the as-prepared catalysts were treated in situ in the catalytic reactor under $\mathrm{H}_{2}(40 \mathrm{~mL} / \mathrm{min})$ for $2 \mathrm{~h}\left(5^{\circ} \mathrm{C} / \mathrm{min}\right)$ at atmospheric pressure in the $450-700{ }^{\circ} \mathrm{C}$ range (standard value $450{ }^{\circ} \mathrm{C}$ ). The catalytic experiments were conducted with an $\mathrm{H}_{2} / \mathrm{CO}_{2} / \mathrm{N}_{2}$ mixture (3:1:1 vol. fractions and $50 \mathrm{~mL} / \mathrm{min}$ total molar flow rate) and $400 \mathrm{mg}$ of catalyst, leading to a gas hourly space velocity (GHSV) of $7500 \mathrm{~mL} \cdot \mathrm{g}^{-1} \cdot \mathrm{h}^{-1}$. The following standard temperature sequence was used for the catalytic tests: from RT to $200^{\circ} \mathrm{C}$ at $5{ }^{\circ} \mathrm{C} / \mathrm{min}$, then 200 ${ }^{\circ} \mathrm{C}$ to $300{ }^{\circ} \mathrm{C}$ at $0.25^{\circ} \mathrm{C} / \mathrm{min}$. 
Conversion of $\mathrm{CO}_{2}\left(\chi_{\mathrm{CO} 2}\right)$, selectivities to product $\mathrm{P}\left(\mathrm{S}_{\mathrm{P}}\right)$, methanol $(\mathrm{MeOH})$ production turnover frequency $\left(\mathrm{TOF}_{\mathrm{MeOH}}\right)$ and space-time yield $\left(S T Y_{\mathrm{MeOH}}\right)$ were calculated as follows, with $Q_{\mathrm{CO}^{\text {in }}}, Q_{i}{ }^{\text {out }}, n_{\mathrm{Mo}}, M_{\mathrm{MeOH}}$, and $m_{\text {cat }}$ representing the molar flow rate of $\mathrm{CO}_{2}$ at the reactor inlet, the molar flow rate of product $i$ at the reactor outlet, the molar amount of Mo, the molar mass of methanol, and the catalyst mass, respectively. For TOF calculations, all Mo atoms were considered as exposed to the gas phase (100\% dispersion).

$\chi_{\mathrm{CO} 2}=\frac{\sum_{i} Q_{i}^{\text {out }}}{Q_{\mathrm{CO} 2}^{\text {in }}} \quad S_{P}=\frac{Q_{P}^{\text {out }}}{\sum_{i} Q_{i}^{\text {out }}} \quad T O F_{\mathrm{MeOH}}=\frac{Q_{\mathrm{CO} 2}^{\text {in }} \chi_{\mathrm{CO} 2} S_{\mathrm{MeOH}}}{n_{\mathrm{Mo}}} \quad S T Y_{\mathrm{MeOH}}=\frac{Q_{\mathrm{CO} 2}^{\text {in }} \chi_{\mathrm{CO} 2} S_{\mathrm{MeOH}} M_{\mathrm{MeOH}} \times 1000}{m_{\mathrm{Cat}}}$

\section{Catalyst characterization}

Scanning transmission electron microscopy (STEM) with high-angle annular dark field (HAADF) detection was performed on a Jeol Cold FEG NeoARM (point-to-point resolution 0.78 Å, images in Figure 1) and a Jeol 2100F (point-to-point resolution $1.1 \AA$, all other images), both equipped with a Cs-corrected condenser at the probe level and operated at $200 \mathrm{kV}$. For sample preparation, the powder was crushed and dispersed in ethanol through ultrasonication, dropped onto a holey carbon-coated 200 mesh $\mathrm{Cu}$ grid, and dried by a lamp. To avoid contamination during analysis and remove any residual carbon, the samples were Ar plasmacleaned for $20 \mathrm{~s}$ (Plasma Prep 5, GaLa Instrumente). No filtering was applied on the STEM images.

NAP-XPS analysis was conducted at the CIRCE beamline at ALBA synchrotron, using a NAPP endstation designed by SPECS GmbH in collaboration with CIRCE beamline. All spectra reported here were acquired combining UHV and $\mathrm{H}_{2} / \mathrm{CO}_{2}$ environments with the sample held at RT, 200 ${ }^{\circ} \mathrm{C}, 275^{\circ} \mathrm{C}$, and $350^{\circ} \mathrm{C}$ while the catalyst run at 2 mbar with a $3 / 1$ ratio of $\mathrm{H}_{2} / \mathrm{CO}_{2}$ mixture. Each sample was previously reduced in situ at $400{ }^{\circ} \mathrm{C}$ under 2 mbar of $\mathrm{H}_{2}$. The catalyst in powder form was deposited onto an Ag foil previously cleaned to reduce charge effects and for XPS calibration purposes. ${ }^{52}$ The spectra are all referenced to the Ag Fermi level, measured after 
every spectrum, to determine absolute binding energies. A Photon energy of $400 \mathrm{eV}$ was used to probe Mo 3d core-level with high photoionization cross-section under NAP conditions. Sample degradation due to X-ray radiation was not observed. NAP-XPS analysis revealed a wellresolved Mo 3d core level. Each spectrum was decomposed into a combination of Voight functions, each with an overall full-width at half maximum (FWHM) of approximately $1.6 \mathrm{eV}$.

Hydrogen-assisted temperature programmed reduction $\left(\mathrm{H}_{2}-\mathrm{TPR}\right)$ was performed using a $\mathrm{U}$ shaped quartz reactor (internal diameter $4 \mathrm{~mm}$ ). Prior to the TPR, the catalyst (100 $\mathrm{mg}$ ) was pretreated under $\mathrm{He}(30 \mathrm{~mL} / \mathrm{min})$ at $250{ }^{\circ} \mathrm{C}\left(15^{\circ} \mathrm{C} / \mathrm{min}\right)$ for $30 \mathrm{~min}$. After returning to room temperature, the catalyst was heated at $15{ }^{\circ} \mathrm{C} / \mathrm{min}$ to $850{ }^{\circ} \mathrm{C}$ under $30 \mathrm{~mL} / \mathrm{min}$ of $1 \% \mathrm{H}_{2} / \mathrm{He}$. The outlet gas mixture was analyzed by an Omnistar mass spectrometer from Pfeiffer Vacuum. The baseline was subtracted to the resulting $\mathrm{H}_{2}$ signal, which is quantified using $1 \% \mathrm{H}_{2} / \mathrm{He}$ as reference value.

Diffuse reflectance ultraviolet-visible spectroscopy (DRUV) was performed with a Perkin Elmer Lambda 45 spectrometer equipped with a deuterium-halogen illumination source and an integrated sphere (RSA-PE-20 $\varnothing=200 \mathrm{~mm}$ ). Barium sulphate (Sigma-Aldrich, 99.99\%) was used as a reference and a diluting powder for samples. In a typical sample preparation, $20 \mathrm{mg}$ of catalyst were diluted in $1 \mathrm{~g}$ of $\mathrm{BaSO}_{4}$, homogenized by grinding in an agate mortar and placed in a sample holder. Reflectance measurements were converted to absorption spectra using the Kubelka-Munk function (K-M).

$\mathrm{CO}_{2}$ temperature-programmed desorption (TPD) measurements were conducted on a custom-made apparatus using a U-glass tubular reactor loaded with $100 \mathrm{mg}$ of catalyst. After an in situ reduction for $2 \mathrm{~h}$ at $450{ }^{\circ} \mathrm{C}\left(5{ }^{\circ} \mathrm{C} / \mathrm{min}\right)$ under $40 \mathrm{~mL} / \mathrm{min}$ of $\mathrm{H}_{2}$, the powder was desorbed at $450{ }^{\circ} \mathrm{C}$ under $\mathrm{N}_{2}(100 \mathrm{~mL} / \mathrm{min})$ for $4 \mathrm{~h}$. After cooling down to $30{ }^{\circ} \mathrm{C}$, the catalyst was exposed to $5 \% \mathrm{CO}_{2}$ in $\mathrm{N}_{2}$. Then, the reactor was flushed for 30 min under $\mathrm{N}_{2}$ before the temperature was increased from $30{ }^{\circ} \mathrm{C}$ to $450{ }^{\circ} \mathrm{C}\left(5{ }^{\circ} \mathrm{C} / \mathrm{min}\right)$ to desorb $\mathrm{CO}_{2}$. The outlet gases 
were analyzed by infrared spectroscopy and the $\mathrm{CO}_{2}$ quantity was determined from the asymmetric stretching bands at $2450-2100 \mathrm{~cm}^{-1}$ using a calibration curve.

X-ray fluorescence (XRF) analysis was performed using an Epsilon 4 spectrometer from Malvern Panalytical. The generator was used at $50 \mathrm{kV}$ and $60 \mu \mathrm{A}$ under air atmosphere. Data were collected at the Mo K $\alpha$ energy level (17.44 keV) using a 3-point calibration curve verified by inductively coupled plasma - optical emission spectroscopy (ICP-OES).

The specific surface areas were determined by $\mathrm{N}_{2}$ volumetry through a 5-points BET method using a Micrometrics ASAP 2020.

\section{Results and discussion}

The catalysts were prepared by conventional wet impregnation followed by a reductive treatment (see Experimental section). The samples, listed in Table 1, are labelled as $<M o$ loading in $w t \%>\mathrm{Mo} /<\mathrm{TiO}_{2}$ material name $>-\mathrm{R}<$ in situ reduction temperature $>$. For example, 3Mo/DT51D-R450 denotes a catalyst containing 3 wt\% Mo supported on $\mathrm{TiO}_{2}$ DT51D (anatase) and reduced in situ at $450^{\circ} \mathrm{C}$. This reduction temperature being the default one, "R450" is often omitted in the following. XRF measurements (Table 1) show that the Mo loadings were found close to the target values ( 0.1 to $10 \mathrm{wt} \%$, standard loading $3 \mathrm{wt} \%$ ) within a relative accuracy of $20 \%$. 
Table 1 - Characteristics of the as-prepared $\mathrm{Mo} / \mathrm{TiO}_{2}$ catalysts used in this study.

\begin{tabular}{cccc}
\hline Sample name & $\begin{array}{c}\text { Specific surface } \\
\text { area }\left(\mathbf{m}^{2} / \mathbf{g}\right)^{\mathrm{a}}\end{array}$ & $\begin{array}{c}\mathrm{TiO}_{2} \text { phase } \\
\text { composition } \\
\text { (anatase/rutile) }^{\mathbf{b}}\end{array}$ & $\begin{array}{c}\text { Mo loading } \\
\text { (wt\%) }^{\mathbf{c}}\end{array}$ \\
\hline 0.1Mo/DT51D & & & 0.1 \\
0.3Mo/DT51D & & $100 \% / 0 \%$ & 0.2 \\
1Mo/DT51D & 78 & & 1.0 \\
3Mo/DT51D & & $100 \% / 0 \%$ & 2.9 \\
10Mo/DT51D & & $90 \% / 10 \%$ & 8.3 \\
3Mo/PC500 & 148 & $80 \% / 20 \%$ & 3.4 \\
3Mo/P90 & 105 & $0 \% / 100 \%$ & 2.8 \\
3Mo/P25 & 61 & $0 \% / 100 \%$ & 2.6 \\
3Mo/RL11A & 12 & & 1.0 \\
1Mo/RNR & 44 & & 2.9 \\
3Mo/RNR & & & 3.3 \\
\hline
\end{tabular}

${ }^{a}$ Determined by $N_{2}$ volumetry through the BET method; ${ }^{b}$ Supplier mass fraction values, except for RNR: determined from $X$ ray diffraction; ${ }^{c}$ Determined by XRF spectroscopy (standard deviation 0.05 wt\%).

Figure 1 displays representative STEM-HAADF micrographs of 3Mo/DT51D and 3Mo/RNR samples. The images suggest that $\mathrm{Mo}$ is atomically dispersed at the surface of $\mathrm{TiO}_{2}$, i.e. it is present as a mixture of single-atoms and subnanometric clusters. The latter correspond to 2D oxomolybdate clusters, as previously reported in the literature. ${ }^{45,53-55}$ STEM micrographs of the other $3 \mathrm{wt} \% \mathrm{Mo} / \mathrm{TiO}_{2}$ catalysts (Figure $\mathrm{S} 1$ ) show a similarly high dispersion of Mo. The color maps in Figures $1 \mathrm{C}$ and $1 \mathrm{~F}$ highlight the relative intensities within the $2 \mathrm{~nm}^{2}$ yellow squares represented in Figures $1 \mathrm{~B}$ and $1 \mathrm{E}$ for anatase and rutile, respectively. Along these two imaging orientations, Mo atoms are seen to preferentially locate at the edges or within the dense layers of the titania lattice for both anatase and rutile. This is consistent with previous experimental and theorical works on the epitaxial growth of $\mathrm{Mo}$ or $\mathrm{MoO}_{\mathrm{x}}$ clusters or layers on anatase (101) or rutile $(110)$ titania. ${ }^{54-58}$ 
A

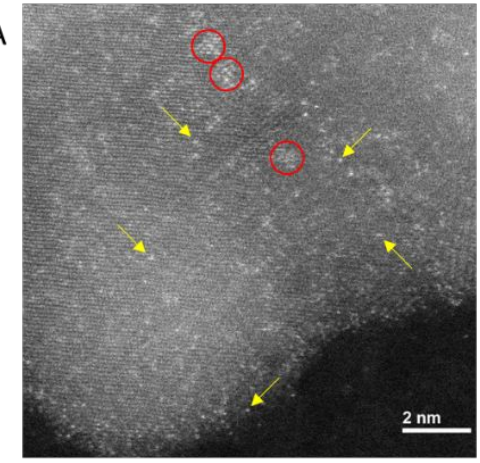

B

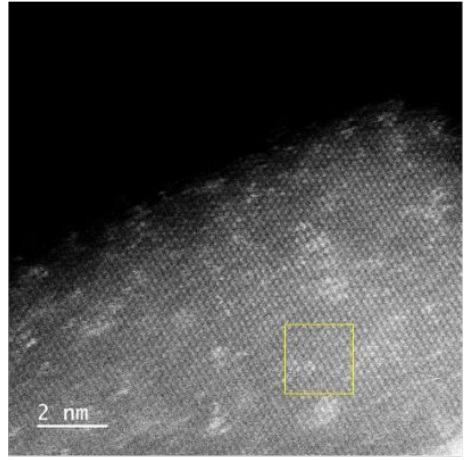

D

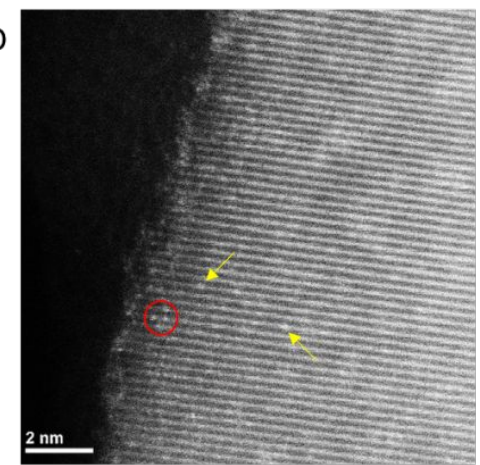

E

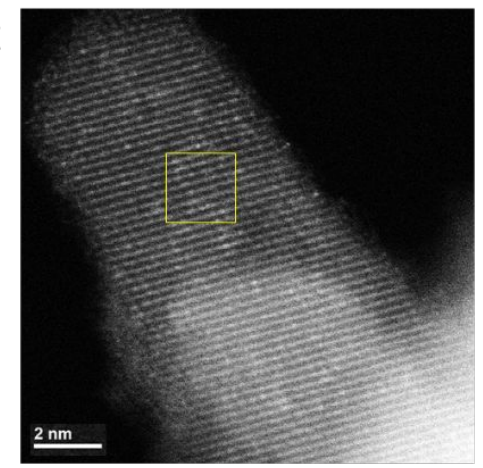

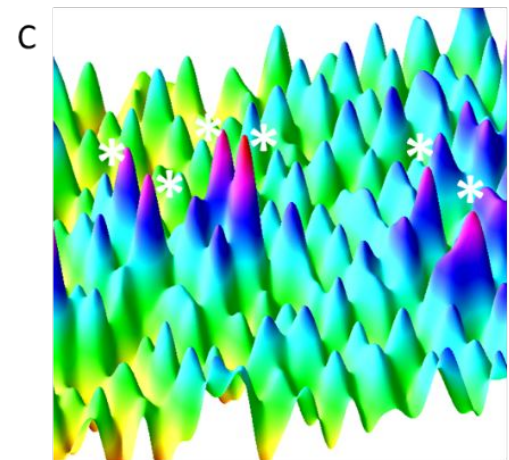

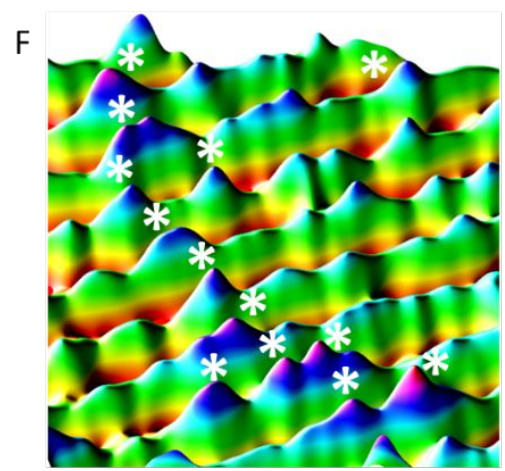

Figure 1 - Representative aberration-corrected STEM-HAADF micrographs. A, B:3Mo/DT51D; D, E: 3Mo/RNR. Arrows and circles in A and D show single Mo atoms and Mo clusters, respectively. C, F: Color-map representation of the intensity in the $2 \mathrm{~nm}^{2}$ yellow square represented in B and $E$, respectively. The white stars indicate the Mo atoms.

A summary of catalytic properties for the whole set of samples is presented in Table 2 . In order to compare the different materials, conversion, selectivity as well as methanol TOF and STY were determined as described in the Experimental section. 


$$
m L \cdot g^{-1} \cdot h^{-1} .
$$

\begin{tabular}{|c|c|c|c|c|c|c|}
\hline Sample & $\begin{array}{c}\mathrm{CO}_{2} \\
\text { conversion } \\
(\%)\end{array}$ & $\begin{array}{c}\mathrm{CH}_{4} \\
\text { selectivity } \\
(\%)^{\mathrm{b}}\end{array}$ & $\begin{array}{c}\mathrm{MeOH} \\
\text { selectivity } \\
(\%)^{b}\end{array}$ & $\begin{array}{c}\text { DME } \\
\text { selectivity } \\
(\%)^{b}\end{array}$ & $\begin{array}{l}\text { MeOH TOF } \\
\left(\mathrm{mol}_{\mathrm{MeOH} \cdot}\right. \\
\mathrm{mol}_{\left.\mathrm{Mo}^{-1} \cdot \mathrm{h}^{-1}\right)}\end{array}$ & $\begin{array}{c}\text { MeOH STY } \\
\left(\mathrm{g}_{\mathrm{MeOH}} \cdot\right. \\
\mathrm{kg}_{\left.\mathrm{cat}^{-1} \cdot \mathrm{h}^{-1}\right)}\end{array}$ \\
\hline DT51D & 0.2 & - & - & - & - & - \\
\hline 0.1Mo/DT51D & 0.9 & 5.2 & 4.8 & 4.8 & 2.81 & 0.94 \\
\hline 0.3Mo/DT51D & 3.0 & 5.9 & 5.1 & 2.5 & 3.20 & 3.20 \\
\hline 1Mo/DT51D & 5.2 & 12.0 & 10.2 & 3.2 & 3.57 & 11.31 \\
\hline $\begin{array}{l}\text { 3Mo/DT51D } \\
\text { as prepared }\end{array}$ & 1.7 & 5.1 & 23.3 & 5.9 & 0.88 & 8.22 \\
\hline 3Mo/DT51D & 4.8 & 8.7 & 6.6 & 3.2 & 0.71 & 6.84 \\
\hline $\begin{array}{c}\text { 3Mo/DT51D } \\
\text {-R600 }\end{array}$ & 10.8 & 6.1 & 5.7 & 1.6 & 1.33 & 12.89 \\
\hline $\begin{array}{c}\text { 3Mo/DT51D } \\
\text {-R700 }\end{array}$ & 3.8 & 3.2 & 15.1 & 0.7 & 1.24 & 12.00 \\
\hline 10Mo/DT51D & 3.3 & 9.5 & 4.9 & 2.2 & 0.12 & 3.41 \\
\hline 3Mo/PC500 & $<0.1$ & - & - & - & - & - \\
\hline 3Mo/P90 & 4.0 & 10.5 & 3.7 & 1.0 & 0.28 & 3.09 \\
\hline 3Mo/P25 & 2.6 & 10.0 & 5.4 & 3.1 & 0.32 & 3.01 \\
\hline 3Mo/RL11A & 1.5 & 4.4 & 17.8 & 0 & 0.57 & 5.68 \\
\hline 1Mo/RNR & 7.6 & 23.1 & 10.5 & 1.1 & 5.16 & 16.87 \\
\hline 3Mo/RNR & 6.8 & 9.3 & 24.2 & 1.3 & 3.61 & 34.95 \\
\hline $\begin{array}{c}50 \mathrm{Cu} / \mathrm{ZnO} / \\
\mathrm{Al}_{2} \mathrm{O}_{3}\end{array}$ & 20.7 & 0 & 32.3 & 0 & 0.56 & 141.06 \\
\hline
\end{tabular}

${ }^{a}$ The samples were prereduced in situ at $450{ }^{\circ} \mathrm{C}$, except when mentioned otherwise; ${ }^{b} \mathrm{CO}$ represents the complement to $100 \%$.

From these data, it appears that titania supports without Mo are inactive whereas all the samples with Mo are active for $\mathrm{CO}_{2}$ hydrogenation, except Mo/PC500 for which the support collapsed upon the catalyst preparation (specific surface area of $150 \mathrm{~m}^{2} / \mathrm{g}$ instead of $350 \mathrm{~m}^{2} / \mathrm{g}$ initially). The main product is always CO (along with water, which cannot be accurately 
quantified), followed by methane or methanol depending on the support oxide, then dimethyl ether (DME). Thus, the main reaction pathway on molybdenum-based catalysts remains $\mathrm{CO}_{2}$ reduction to $\mathrm{CO}$ through the reverse water-gas shit reaction as described by several groups using molybdenum carbide, $\mathrm{MoO}_{x} / \mathrm{Ti}_{3} \mathrm{AlC}_{2}$ or molybdenum doping $\mathrm{Fe} / \mathrm{Al}_{2} \mathrm{O}_{3}$ and $\mathrm{Cu} / \mathrm{FAU} .{ }^{59-63}$

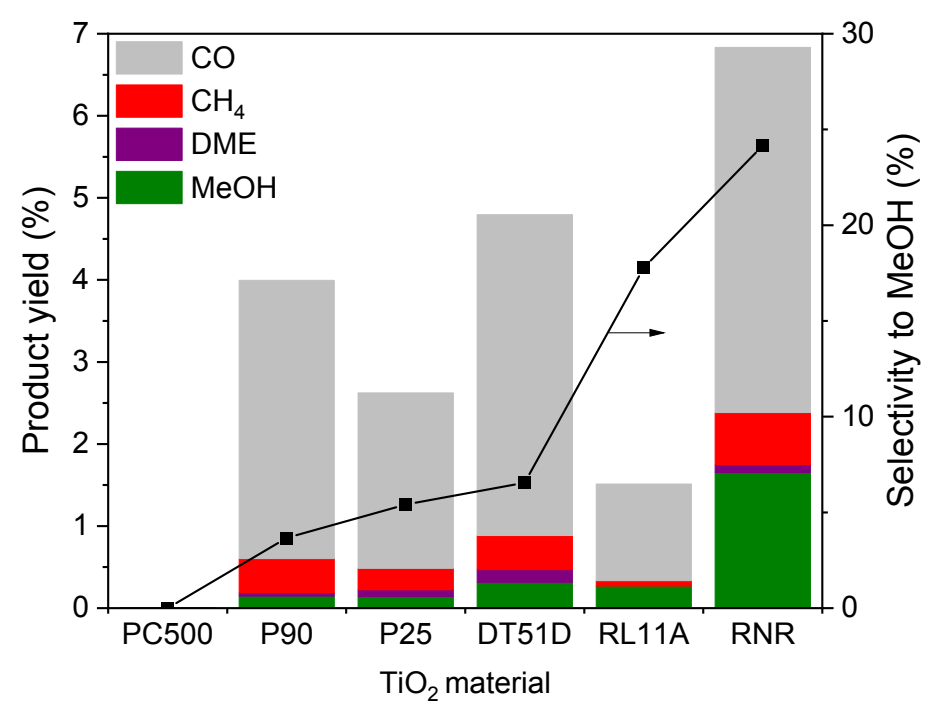

Figure 2 - Effect of $\mathrm{TiO}_{2}$ nature on product yields and methanol selectivity for $3 \mathrm{Mo} / \mathrm{TiO}_{2}$ catalysts at $275^{\circ} \mathrm{C}$ under 30 bar of $\mathrm{H}_{2} / \mathrm{CO}_{2} / \mathrm{N}_{2}(3 / 1 / 1), \mathrm{GHSV}=7500 \mathrm{~mL} \cdot \mathrm{g}^{-1} \cdot \mathrm{h}^{-1}$.

Figure 2 allows comparing the titania supports in terms of $\mathrm{CO}_{2}$ hydrogenation activity and selectivity to methanol at a constant Mo loading of $3 \mathrm{wt} \%$. The $\mathrm{CO}_{2}$ conversion at $275^{\circ} \mathrm{C}$ varies from less than $0.1 \%$ for PC500 to $6.8 \%$ for RNR. The products distribution also strongly depends on the $\mathrm{TiO}_{2}$ nature. In particular, the selectivity to methanol ranges from $3.7 \%$ for $\mathrm{P} 90$ to $24.2 \%$ for RNR. As a result, the STY reaches $35 \mathrm{~g}$ of methanol per kg of catalyst per hour, versus 141 $\mathrm{g}_{\text {меон }} \cdot \mathrm{kg}_{\mathrm{cat}}{ }^{-1} \cdot \mathrm{h}^{-1}$ for the highly Cu-loaded (50 wt\%) $\mathrm{Cu} / \mathrm{ZnO} / \mathrm{Al}_{2} \mathrm{O}_{3}$ commercial methanolsynthesis catalyst evaluated in the same conditions (Figure S2).

The results of typical experiments at variable temperature are reported in Figure S3 for 3Mo/RNR and 3Mo/DT51D, the two most active systems. $\mathrm{CO}_{2}$ conversion as well as selectivities to $\mathrm{CH}_{4}$ and $\mathrm{CO}$ increase with the temperature, whereas the selectivity to methanol decreases. 
While the $3 \mathrm{Mo} / \mathrm{RNR}$ catalyst reaches a methanol selectivity of $50 \%$ at $200{ }^{\circ} \mathrm{C}$, a maximum of 23 $\%$ is obtained at $220^{\circ} \mathrm{C}$ on 3Mo/DT51D, with CO as the main by-product for the two catalysts. These two catalysts exhibit stable catalytic performance for $40 \mathrm{~h}$ (Figure S4).

Notably, these performances correlate neither with the specific surface area of $\mathrm{TiO}_{2}$ (Figure S5), nor with the titania phase composition as anatase-pure DT51D and rutile-pure RNR are the supports that promote the highest activities. A same $\mathrm{TiO}_{2}$ phase can be synthetized by different preparation methods - including sol-gel methods, hydrothermal treatments (RNR), and flame pyrolysis (P25, P90) - that produce crystalline powders with substantially different exposed facets with different reactivities. ${ }^{64}$

Synchrotron-based NAP-XPS was performed to tentatively clarify the atomic origins of the support-dependent performances in terms of Mo oxidation state. The experiments were carried out on 3Mo/RNR, 3Mo/P25, and 3Mo/DT51D under conditions of in situ reduction $\left(\mathrm{H}_{2}\right.$, $400{ }^{\circ} \mathrm{C}$ ) and reaction $\left(75\right.$ vol\% $\mathrm{H}_{2}+25$ vol\% $\mathrm{CO}_{2}, 200-350{ }^{\circ} \mathrm{C}$ ) at 2 mbar total pressure. As an example, Figure 3A shows Mo 3d core-level spectra for 3Mo/DT51D and 3Mo/RNR under $\mathrm{H}_{2}-$ $\mathrm{CO}_{2}$ mixture at $275{ }^{\circ} \mathrm{C}$. The XPS results obtained for all the samples and conditions are presented in Figure S6 and Table S1, and synthetized in Figure 3B. A clear impact of the nature of the $\mathrm{TiO}_{2}$ support on the Mo oxidation states distribution is observed. As a matter of fact, Mo is more reduced on rutile (RNR) than on anatase (DT51D), the dominant states being $\mathrm{Mo}^{\vee}$ and $\mathrm{Mo}^{\mathrm{VI}}$, respectively. Mixed-phase P25 exhibits an intermediate $\mathrm{Mo} / \mathrm{Mo}^{\mathrm{VI}}$ ratio. Whereas the state of Mo on DT51D hardly changes, an overall oxidation of Mo occurs on RNR and P25 when switching from reduction to reaction conditions. This is ascribed to $\mathrm{CO}_{2}$ and/or $\mathrm{H}_{2} \mathrm{O}$ acting as oxidizing agents, ${ }^{65-67}$ and to the more labile oxygen environment of Mo on rutile than on anatase, which may relate to the higher reducibility of the rutile surface with respect to anatase. ${ }^{68}$ Under NAP-XPS reaction conditions, Mo/RNR is the only catalyst containing MolV species. The latter may be at the origin of the significant methanol production activity exhibited by Mo/RNR. However, the oxidation state of Mo/P25 comprised between those of DT51D and 
RNR counterparts though its catalytic performance is the lowest (Figure 2). Moreover, the NAPXPS pressure conditions ( 2 mbar total pressure in all cases) are obviously not representative of those employed in the laboratory catalytic reactor (1 bar of $\mathrm{H}_{2}$ for reduction, and 18 bar $\mathrm{H}_{2}+6$ bar $\mathrm{CO}_{2}$ for reaction). Thus, the measured Mo state differences between the supports should be considered qualitatively, and they are not sufficient to explain the catalytic data.

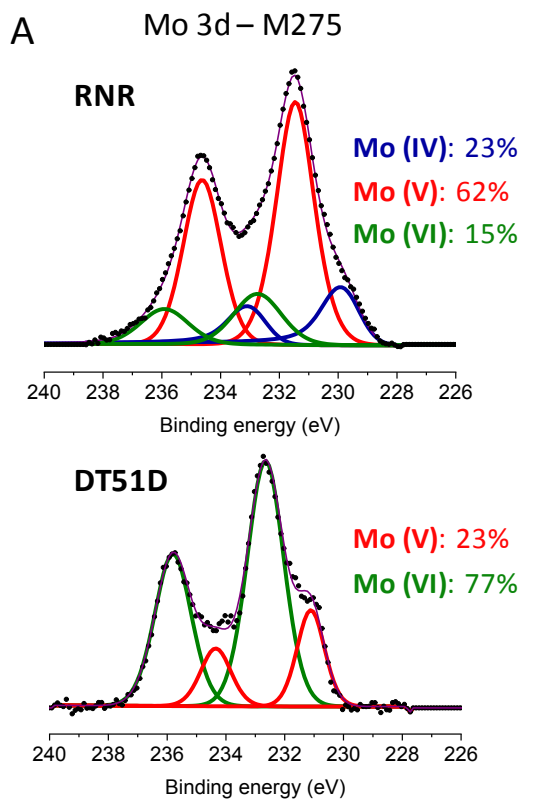

B

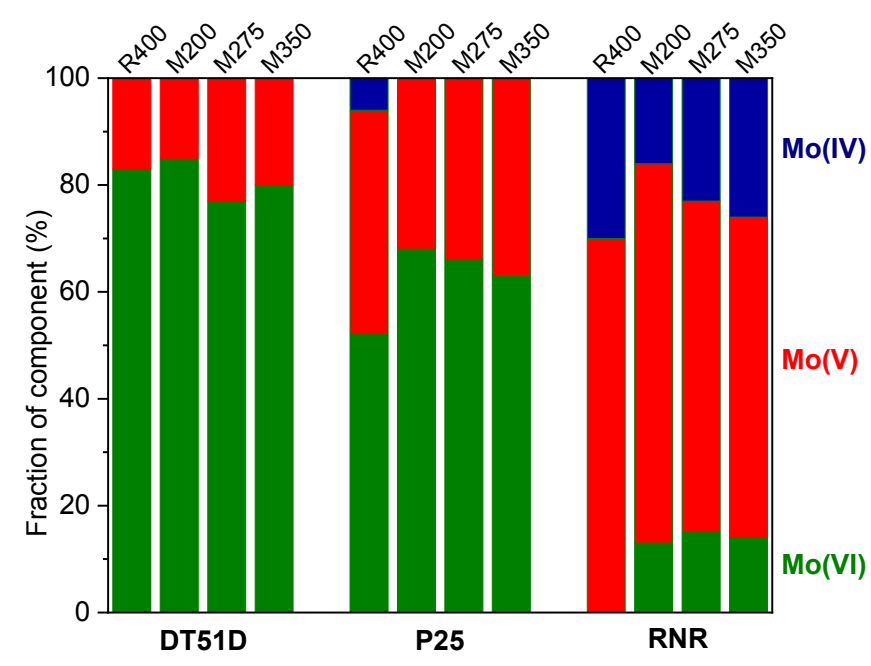

Figure 3-A: Mo 3d NAP-XPS analysis at $275^{\circ} \mathrm{C}$ under 2 mbar of a $3 / 1 \mathrm{H}_{2} / \mathrm{CO}_{2}$ mixture on $3 \mathrm{Mo} / \mathrm{RNR}$ (top) and 3Mo/DT51D (bottom). B: Mo oxidation state distribution in 3 wt\% Mo supported on DT51D, P25 and RNR $\mathrm{TiO}_{2}$ determined from NAP-XPS (Mo 3d), during in situ reduction at $400{ }^{\circ} \mathrm{C}(\mathrm{R} 400)$, and exposure to $\mathrm{CO}_{2} / \mathrm{H}_{2}$ reactant mixture $(3 / 1)$ at $200{ }^{\circ} \mathrm{C}(\mathrm{M} 200), 275{ }^{\circ} \mathrm{C}$ (M275) and $350^{\circ} \mathrm{C}$ (M350). 


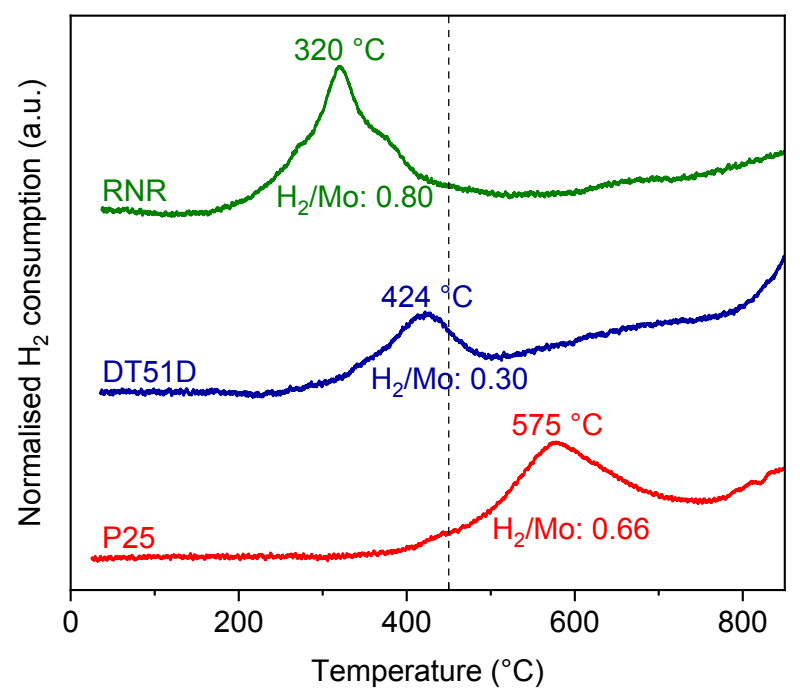

Figure $4-H_{2}-T P R$ profiles for 3 wt\% Mo supported on RNR, DT51D and P25 titania. The temperatures of maximum consumption and the $\mathrm{H}_{2}$-to-Mo molar ratios, i.e. area of the TPR peak normalised over the amount of Mo, are indicated. The temperature of in situ reduction pretreatment employed for catalytic tests $\left(450^{\circ} \mathrm{C}\right)$ is displayed with a vertical dotted line.

In order to gain insight into the reducibility of molybdenum on these three $\mathrm{TiO}_{2}$ supports, $\mathrm{H}_{2}$-TPR experiments were carried out, as shown in Figure 4. Two types of hydrogen consumption features can be distinguished: a fast main one identifiable by a TPR peak, and a slower and continuous one at higher temperature. Regarding the main feature, on the one hand the amount of $\mathrm{H}_{2}$ consumed per Mo atom increases with the fraction of rutile phase (i.e. from DT51D to RNR), consistently with the NAP-XPS data showing the lowest overall oxidation state for Mo on RNR. On the other hand, the TPR peak position varies from $320^{\circ} \mathrm{C}$ to $424{ }^{\circ} \mathrm{C}$ and $575{ }^{\circ} \mathrm{C}$ for RNR, DT51D and P25, respectively. This peak can be assigned to the reduction of well-dispersed octahedral Mo ${ }^{\mathrm{VI}}$ species. ${ }^{69-71}$ The last reduction event occurring above $800{ }^{\circ} \mathrm{C}$ for anatase-containing samples can be attributed to tetrahedral $\mathrm{Mo}^{\mathrm{VI}}$ species. $^{72}$ As no significant $\mathrm{H}_{2}$ consumption was observed for the bare supports, the continuous TPR feature occurring after the main reduction event can be explained by the slow reduction of polymeric oxomolybdate species. ${ }^{70}$ In addition, molybdenum species can promote the partial reduction 
of titanium to $\mathrm{Ti}^{3+}$ in the near-surface region, ${ }^{73}$ and the structural similarity of rutile $\mathrm{TiO}_{2}$ and $\mathrm{MoO}_{2}$ phases may maximize their interaction.

Overall, key factors for methanol productivity may not only be the lower Mo oxidation state (XPS) but also its higher reducibility at low temperature (TPR), both depending on the nature of the $\mathrm{TiO}_{2}$ surface and being favored on RNR.

In an attempt to better understand the influence of the Mo oxidation state on the catalytic performance, the effect of the in situ reduction temperature $\left(450-700^{\circ} \mathrm{C}\right)$ was investigated for 3Mo/DT51D. Figure S7 shows that the catalyst is already slightly active in the absence of in situ pretreatment. After in situ reduction at $450{ }^{\circ} \mathrm{C}, \mathrm{CO}_{2}$ conversion is much higher, and it presents a maximum after treatment at $600{ }^{\circ} \mathrm{C}$. However, the selectivity to methanol shows an opposite behavior, i.e. a minimum for the R600 sample. The increase in conversion being superior to the decrease in selectivity, the methanol TOF $\left(1.4 \mathrm{~h}^{-1}\right)$ is maximal after reduction at $600{ }^{\circ} \mathrm{C}$. As shown by the STEM images in Figure S8, 3Mo/DT51D seems structurally stable at $450{ }^{\circ} \mathrm{C}$, with no obvious effect of the in situ treatment on Mo dispersion. However, Mo sintering occurred for the $\mathrm{R} 600$ sample, as revealed by the presence of $\mathrm{MoO}_{\mathrm{x}}$ nanoparticles of $2.0 \pm 0.5 \mathrm{~nm}$ in size. The stability of these particles, even after re-exposure to ambient air, can be related to the epitaxial growth of the partially reduced Mo oxide on $\mathrm{TiO}_{2} \cdot{ }^{54-58}$ This sintering could lead to a change of active site from the $\mathrm{MoO}_{x}-\mathrm{TiO}_{2}$ interface to the $\mathrm{MoO}_{x}$ surface. A reducing treatment at $700{ }^{\circ} \mathrm{C}$ induces the formation of even larger $\mathrm{MoO}_{x}$ particles $(2.7 \pm 0.5 \mathrm{~nm})$ and the sintering of titania (Figure S9), which loses part of its specific surface area (from $78 \mathrm{~m}^{2} / \mathrm{g}$ for R450 catalysts to 58 and $20 \mathrm{~m}^{2} / \mathrm{g}$ for their $\mathrm{R} 600$ et R700 counterparts, respectively). These phenomena could explain the significant drop in activity after treatment at $700{ }^{\circ} \mathrm{C} .{ }^{74}$ Overall, these results indicate that the formation of stable nanoparticles with a lower oxidation state of $\mathrm{Mo}$ is favorable to the $\mathrm{CO}_{2}$ conversion rate, but not to methanol selectivity. Note that this observation as well as the heterogeneity of the dispersed Mo phase induced by reducing 
pretreatments at temperatures higher than $500{ }^{\circ} \mathrm{C}$ led us to select $450{ }^{\circ} \mathrm{C}$ as the standard prereduction temperature for all catalysts.

Finally, the impact of the Mo loading (0.1-10 wt\%) on the catalytic performance was investigated for Mo/DT51D-R450. The STEM images in Figure 5A show that Mo remains welldispersed on titania without the formation of stable 3D nanoparticles even at high coverage, though Mo oxide clusters (polymeric oxomolybdates) gradually replace single Mo atoms (monomeric oxomolybdates) as the Mo coverage increases. At $10 \mathrm{wt} \% \mathrm{Mo}$, the cluster size determined from STEM is $0.8 \pm 0.2 \mathrm{~nm}$. In the literature, polymeric ${ }^{75-80}$ and monomeric ${ }^{81-84}$ oxomolybdate species are described as the most active species depending on the studies. DRUV spectroscopy was performed to further characterise molybdate species in catalysts with different loadings. The two contributions of $\mathrm{TiO}_{2}$ centred at $c a .255$ and $310 \mathrm{~nm}$ are clearly observable in Figure S10. A close view of the $350-800 \mathrm{~nm}$ range (Figure 5B) reveals two broad contributions associated with oxomolybdates species. While the one located in the 400-500 $\mathrm{nm}$ range (explaining the yellow colour of the samples) for all catalysts corresponds to $\mathrm{Mo}^{6+}$, the contribution above $550 \mathrm{~nm}$ (blue colour) for highly loaded catalysts is attributed to $\mathrm{Mo}^{5+} .85$ Moreover, $\mathrm{Mo}^{5+}$ can be associated to polymolybdates. ${ }^{86,87}$ Thus, consistently with STEM, the low-loaded catalysts ( $<3 \mathrm{wt} \% \mathrm{Mo}$ ) are covered with ultradispersed oxomolybdate species, whereas the highly loaded catalysts ( $3 \mathrm{wt} \% \mathrm{Mo}$ ) also exhibit larger Mo oxide clusters. The 3Mo/DT51D sample shows an intermediate state. In addition, 3Mo/P25 and 3Mo/RNR catalysts behave similarly as 3Mo/DT51D, as shown by Figure S11. 

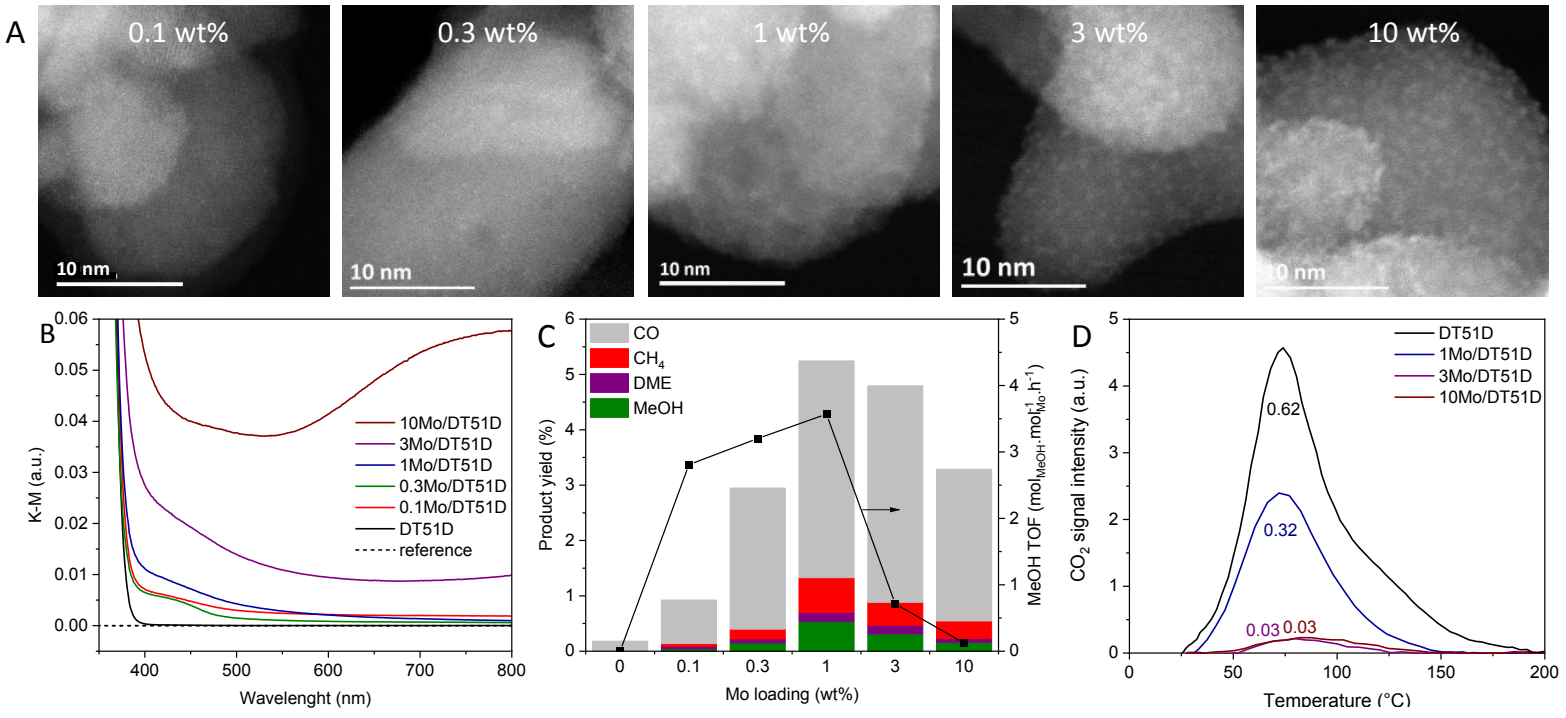

Figure 5 - A: Representative aberration-corrected STEM-HAADF micrographs of 0.1-10 wt\% Mo/DT51D catalysts. B : Diffuse reflectance UV-vis spectra of 0-10 wt\% Mo/DT51D samples in the 350-800 nm range. C: Effect of Mo loading on $\mathrm{CO} / \mathrm{MeOH} / \mathrm{CH}_{4} / \mathrm{DME}$ yields and methanol STY for 0-10 wt\% Mo/DT51D-R450 at $275{ }^{\circ} \mathrm{C}$ under 30 bar of $\mathrm{H}_{2} / \mathrm{CO}_{2} / \mathrm{N}_{2}(3 / 1 / 1)$, GHSV $=7500 \mathrm{~mL} \cdot \mathrm{g}^{-1} \cdot \mathrm{h}^{-1} \cdot \mathrm{D}: \mathrm{CO}_{2}$-TPD profiles for $100 \mathrm{mg}$ of 0-10 wt\% Mo/DT51D samples. The total amount of desorbed $\mathrm{CO}_{2}$ in $\mu \mathrm{mol} / \mathrm{m}^{2}$ is indicated.

Figure $5 \mathrm{C}$ shows an optimum in $\mathrm{CO}_{2}$ conversion (5.2\%) and methanol selectivity (10.2\%) for $1 \mathrm{wt} \% \mathrm{Mo}$ at $275^{\circ} \mathrm{C}$. This corresponds to a maximal methanol TOF of $3.6 \mathrm{~h}^{-1}$. The decrease in $\mathrm{CO}_{2}$ conversion below 1 wt\% Mo is ascribed to a limiting number of active sites. However, the $\mathrm{MeOH}$ TOF remains nearly stable in the $0.1-1 \mathrm{wt} \%$ Mo loading range. This is assigned to the presence of mainly isolated oxomolybdate species on these three catalysts, which is in accordance with the DRUV spectra. Note also that in this "single atom" state, the length of the $\mathrm{MoO}_{\mathrm{x}}-\mathrm{TiO}_{2}$ interface accessible to reactants is maximized. As the coverage increases and polymeric oxomolybdates form, some Mo atoms are no longer in contact with the accessible surface of titania. Thus, dual $\mathrm{MoO}_{x}-\mathrm{TiO}_{2}$ sites may be essential to methanol productivity, as the $\mathrm{Cu}-\mathrm{ZnO}$ sites are for the classical $\mathrm{Cu} / \mathrm{ZnO} / \mathrm{Al}_{2} \mathrm{O}_{3}$ methanol-synthesis catalyst. ${ }^{88}$

The $\mathrm{CO}_{2}$-TPD curves in Figure 5D show that the amount of $\mathrm{CO}_{2}-$ adsorbed on the catalyst at $\mathrm{RT}$ and desorbed in the RT- $450^{\circ} \mathrm{C}$ range - decreases as the Mo loading increases, and vanishes to almost zero for $3 \mathrm{wt} \%$ Mo and above. Consistently with the previous hypothesis, we attribute 
the impact of the Mo loading on the catalytic properties to a balance between the number of basic sites on $\mathrm{TiO}_{2}$ available for $\mathrm{CO}_{2}$ adsorption ${ }^{89}$ and that of $\mathrm{Mo}$ centers enabling $\mathrm{H}_{2}$ activation and $\mathrm{CO}_{2}$ conversion at the exposed $\mathrm{MoO}_{x}-\mathrm{TiO}_{2}$ interface. A similar methanol activity tendency is observed for Mo/RNR with a MeOH TOF at $275^{\circ} \mathrm{C}$ reaching $5.2 \mathrm{~h}^{-1}$ for the 1 wt\% Mo catalyst (Figure S12). Again, we ascribe this behavior to the higher methanol production performance of isolated oxomolybdate species.

\section{Conclusion}

In conclusion, we have demonstrated the possibility to obtain efficient catalysts based on titania-supported ultradispersed molybdenum species for $\mathrm{CO}_{2}$ hydrogenation, here performed under gas-phase conditions at $3 \mathrm{MPa}$. The main products are $\mathrm{CO}$, methane and methanol. The $\mathrm{TiO}_{2}$ support type, as well as the Mo loading and the reductive pretreatment temperature, substantially impact the catalytic activity and selectivity.

From a combination of characterization techniques such as aberration-corrected STEM, NAPXPS, DRUV and temperature-programmed methods, we reach the following conclusions. A low Mo coverage corresponding to ca. $1 \mathrm{wt} \%$ Mo provides an optimal compromise, in terms of methanol yield, between the number of active sites and their isolation. The most active sites for methanol production are associated to Mo oxo species, either isolated on titania or located at the periphery of polymolybdate clusters. In these dual $\mathrm{MoO}_{x}-\mathrm{TiO}_{2}$ sites, molybdenum ideally exhibits labile and partial oxidation states - possibly $\mathrm{Mo}^{\mathrm{Iv}}$. The presence of these sites appears to strongly depend on the titania surface structure. The highest performance was measured for a titania support consisting of rutile nanorods, with a methanol STY of $35 \mathrm{~g}_{\mathrm{MeOH}} \cdot \mathrm{kg}_{\mathrm{cat}}{ }^{-1} \cdot \mathrm{h}^{-1}$ at $275^{\circ} \mathrm{C}$

Forthcoming studies on the $\mathrm{Mo} / \mathrm{TiO}_{2}$ system will rely on advanced operando investigations and theoretical modelling, with the aim of understanding how the Mo atom coordination and oxidation state, as well as the titania surface structure and acid-base properties (including the 
presence of $\mathrm{TiO}_{2}$ vacancies ${ }^{90,91}$ ), affect the catalytic properties. A better knowledge of the structure-function relationships will enable further improvement of the catalysts reported herein.

\section{Authors contributions}

LP conceptualized the study, acquired the funding, and managed the project; TL and NP prepared the catalysts; TL carried out routine materials characterization, temperatureprogrammed experiments, and catalytic tests; $\mathrm{MB}, \mathrm{OE}$, and $\mathrm{YL}$ performed the STEM analyses; LC, IJVG, VPD and JL performed the NAP-XPS experiments; LC analysed the NAP-XPS data; EP performed the DRUV experiments and analysed the data; PA prepared the $\mathrm{TiO}_{2} \mathrm{RNRs}$; RC set up the catalytic bench; LP, FM, PA and NP supervised the PhD thesis of TL; TL, LP and FM wrote the original draft; All the authors reviewed the paper.

\section{Conflicts of interest}

There are no conflicts of interest to declare.

\section{Acknowledgment}

A. Nassereddine (IRCELYON) is acknowledged for preliminary catalysis experiments. Y. Lefkir \& S. Reynaud (Laboratoire Hubert Curien) and M. Aouine (IRCELYON) are acknowledged for their support in STEM analysis. CLYM is acknowledged for access to the FEI Titan and Jeol NeoARM microscopes. N. Bonnet \& P. Mascunan (IRCELYON) are acknowledged for XRF and BET analyses. Agence Nationale de la Recherche (UltraCat project, ANR-17-CE06-0008) is acknowledged for financial support. JL is a Serra Húnter Fellow and is grateful to the ICREA Academia program and projects MICINN/FEDER RTI2018-093996-B-C31 and GC 2017 SGR 128. 


\section{References}

1 European Commission, Climate strategies \& targets, https://ec.europa.eu/clima/policies/strategies_en

2 X.-B. Lu, B. Liang, Y.-J. Zhang, Y.-Z. Tian, Y.-M. Wang, C.-X. Bai, H. Wang and R. Zhang, J. Am. Chem. Soc., 2004, 126, 3732-3733.

3 J. Ma, N. Sun, X. Zhang, N. Zhao, F. Xiao, W. Wei and Y. Sun, Catal. Today, 2009, 148, 221-231.

4 M. North and R. Pasquale, Angew. Chem. Int. Ed., 2009, 48, 2946-2948.

5 K. Atsonios, K. D. Panopoulos and E. Kakaras, Int. J. Hydrog. Energy, 2016, 41, 2202-2214.

6 J. C. Abanades, E. S. Rubin, M. Mazzotti and H. J. Herzog, Energy Environ. Sci., 2017, 10, 24912499.

7 X. Nie, W. Li, X. Jiang, X. Guo and C. Song, Adv. Catal., 2019, 65, 121-233.

8 S. Saeidi, N. A. S. Amin and M. R. Rahimpour, J. CO2 Util., 2014, 5, 66-81.

9 F. J. Caparrós, L. Soler, M. D. Rossell, I. Angurell, L. Piccolo, O. Rossell and J. Llorca, ChemCatChem, 2018, 10, 2365-2369.

10 M. Abou Hamdan, A. Nassereddine, R. Checa, M. Jahjah, C. Pinel, L. Piccolo and N. Perret, Front. Chem., 2020, 8, 452.

11 M. Bowker, ChemCatChem, 2019, 11, 4238-4246.

12 A. Álvarez, A. Bansode, A. Urakawa, A. V. Bavykina, T. A. Wezendonk, M. Makkee, J. Gascon and F. Kapteijn, Chem. Rev., 2017, 117, 9804-9838.

13 E. Alberico and M. Nielsen, Chem. Commun., 2015, 51, 6714-6725.

14 G. A. Olah, Angew. Chem. Int. Ed., 2005, 44, 2636-2639.

15 C. Huang, J. Wen, Y. Sun, M. Zhang, Y. Bao, Y. Zhang, L. Liang, M. Fu, J. Wu, D. Ye and L. Chen, Chem. Eng. J., 2019, 374, 221-230.

16 D. F. Carvalho, G. C. Almeida, R. S. Monteiro and C. J. A. Mota, Energy Fuels, 2020, 34, 7269-7274. 17 Z. Wang, H. Song, H. Pang, Y. Ning, T. D. Dao, Z. Wang, H. Chen, Y. Weng, Q. Fu, T. Nagao, Y. Fang and J. Ye, Appl. Catal. B Environ., 2019, 250, 10-16.

18 R. Yang, X. Yu, Y. Zhang, W. Li and N. Tsubaki, Fuel, 2008, 87, 443-450.

19 M. Behrens, F. Studt, I. Kasatkin, S. Kühl, M. Hävecker, F. Abild-Pedersen, S. Zander, F. Girgsdies, P. Kurr, B.-L. Kniep, M. Tovar, R. W. Fischer, J. K. Nørskov and R. Schlögl, Science, 2012, 336, 893897.

20 E. L. Kunkes, F. Studt, F. Abild-Pedersen, R. Schlögl and M. Behrens, J. Catal., 2015, 328, 43-48.

21 R. Gaikwad, H. Reymond, N. Phongprueksathat, P. R. von Rohr and A. Urakawa, Catal. Sci.

Technol., 2020, 10, 2763-2768.

22 Element Scarcity - EuChemS Periodic Table, https://www.euchems.eu/euchems-periodic-table/,

23 B. Liang, J. Ma, X. Su, C. Yang, H. Duan, H. Zhou, S. Deng, L. Li and Y. Huang, Ind. Eng. Chem. Res., 2019, 58, 9030-9037.

24 O. Martin and J. Pérez-Ramírez, Catal. Sci. Technol., 2013, 3, 3343-3352.

25 J. Zhong, X. Yang, Z. Wu, B. Liang, Y. Huang and T. Zhang, Chem. Soc. Rev., 2020, 49, 1385-1413.

26 K. W. Ting, T. Toyao, S. M. A. H. Siddiki and K. Shimizu, ACS Catal., 2019, 9, 3685-3693.

27 O. Martin, A. J. Martín, C. Mondelli, S. Mitchell, T. F. Segawa, R. Hauert, C. Drouilly, D.

Curulla-Ferré and J. Pérez-Ramírez, Angew. Chem. Int. Ed., 2016, 55, 6261-6265.

28 M. S. Frei, C. Mondelli, M. I. M. Short and J. Pérez-Ramírez, ChemSusChem, 2020, 13, 6330-6337.

29 L. Piccolo, Catal. Today, 2020, 373, 80-97.

30 H. Zhang, G. Liu, L. Shi and J. Ye, Adv. Energy Mater., 2018, 8, 1701343.

31 A. Wang, J. Li and T. Zhang, Nat. Rev. Chem., 2018, 2, 65-81.

32 S. Mitchell, E. Vorobyeva and J. Pérez-Ramírez, Angew. Chem. Int. Ed., 2018, 57, 15316-15329.

33 S. Liang, C. Hao and Y. Shi, ChemCatChem, 2015, 7, 2559-2567.

34 L. Liu, U. Díaz, R. Arenal, G. Agostini, P. Concepción and A. Corma, Nat. Mater., 2017, 16, 132-138.

35 L. Liu, D. N. Zakharov, R. Arenal, P. Concepcion, E. A. Stach and A. Corma, Nat. Commun., 2018, 9, 574.

36 Y. Zhang, M. Kubů, M. Mazur and J. Čejka, Microporous Mesoporous Mater., 2019, 279, 364-370. 
37 Y. Zhang, M. Kubů, M. Mazur and J. Čejka, Catal. Today, 2019, 324, 135-143.

38 C. Dessal, A. Sangnier, C. Chizallet, C. Dujardin, F. Morfin, J.-L. Rousset, M. Aouine, M. Bugnet, P. Afanasiev and L. Piccolo, Nanoscale, 2019, 11, 6897-6904.

39 C. Dessal, T. Len, F. Morfin, J.-L. Rousset, M. Aouine, P. Afanasiev and L. Piccolo, ACS Catal., 2019, 9, 5752-5759.

40 C. Dessal, L. Martínez, C. Maheu, T. Len, F. Morfin, J. L. Rousset, E. Puzenat, P. Afanasiev, M.

Aouine, L. Soler, J. Llorca and L. Piccolo, J. Catal., 2019, 375, 155-163.

41 S. Zaman and K. J. Smith, Catal. Rev., 2012, 54, 41-132.

42 C. Wang, D. Wang, S. Liu, P. Jiang, Z. Lin, P. Xu, K. Yang, J. Lu, H. Tong, L. Hu, W. Zhang and Q. Chen, J. Catal., 2020, 389, 150-156.

43 M. Khan, J. Xu, W. Cao and Z.-K. Liu, J. Nanosci. Nanotechnol., 2014, 14, 6865-6871.

44 K. Chen, S. Xie, A. T. Bell and E. Iglesia, J. Catal., 2000, 195, 244-252.

45 J. Faye, M. Capron, A. Takahashi, S. Paul, B. Katryniok, T. Fujitani and F. Dumeignil, Energy Sci.

Eng., 2015, 3, 115-125.

46 D. Wang, W. Qian, A. Ishihara and T. Kabe, Appl. Catal. Gen., 2002, 224, 191-199.

47 J. Ramirez, L. Cedeño and G. Busca, J. Catal., 1999, 184, 59-67.

48 J. Ramirez, S. Fuentes, G. Díaz, M. Vrinat, M. Breysse and M. Lacroix, Appl. Catal., 1989, 52, $211-$ 224.

49 J. Barrault and J. Urresta, Comptes Rendus Académie Sci. - Ser. IIC - Chem., 1999, 2, 167-174.

50 M. Y. Kim, S. B. Ha, D. J. Koh, C. Byun and E. D. Park, Catal. Commun., 2013, 35, 68-71.

51 T. Toyao, S. Kayamori, Z. Maeno, S. M. A. H. Siddiki and K. Shimizu, ACS Catal., 2019, 9, 81878196.

52 C. Maheu, L. Cardenas, E. Puzenat, P. Afanasiev and C. Geantet, Phys. Chem. Chem. Phys., 2018, 20, 25629-25637.

53 H. Hu, I. E. Wachs and S. R. Bare, J. Phys. Chem., 1995, 99, 10897-10910.

54 A. Tougerti, E. Berrier, A.-S. Mamede, C. La Fontaine, V. Briois, Y. Joly, E. Payen, J.-F. Paul and S. Cristol, Angew. Chem. Int. Ed., 2013, 52, 6440-6444.

55 H. Hu, D. Oliveira de Souza, E. Berrier, J.-F. Paul, C. La Fontaine, V. Briois, S. Cristol and A. Tougerti, J. Phys. Chem. C, 2019, 123, 18325-18335.

56 B. Domenichini, M. Petukhov, G. A. Rizzi, M. Sambi, S. Bourgeois and G. Granozzi, Surf. Sci., 2003, 544, 135-146.

57 G. A. Rizzi, A. E. Reeder, S. Agnoli and G. Granozzi, Surf. Sci., 2006, 600, 3345-3351.

58 P. Krüger, J. Phys. Chem. C, 2009, 113, 5308-5312.

59 M. Nagai and T. Kurakami, J. Chem. Eng. Jpn., 2005, 38, 807-812.

60 A. G. Kharaji, A. Shariati and M. A. Takassi, Chin. J. Chem. Eng., 2013, 21, 1007-1014.

61 A. Okemoto, M. R. Harada, T. Ishizaka, N. Hiyoshi and K. Sato, Appl. Catal. Gen., 2020, 592, 117415.

62 Y. Ma, Z. Guo, Q. Jiang, K.-H. Wu, H. Gong and Y. Liu, J. Energy Chem., 2020, 50, 37-43.

63 M. Ronda-Lloret, L. Yang, M. Hammerton, V. S. Marakatti, M. Tromp, Z. Sofer, A. Sepúlveda-

Escribano, E. V. Ramos-Fernandez, J. J. Delgado, G. Rothenberg, T. Ramirez Reina and N. R. Shiju, ACS Sustain. Chem. Eng., 2021, 9, 4957-4966.

64 M. J. Uddin, F. Cesano, A. R. Chowdhury, T. Trad, S. Cravanzola, G. Martra, L. Mino, A. Zecchina and D. Scarano, Front. Mater., , DOI:10.3389/fmats.2020.00192.

65 L. Zhang, Z. Wu, N. C. Nelson, A. D. Sadow, I. I. Slowing and S. H. Overbury, ACS Catal., 2015, 5, 6426-6435.

66 T. Lee, S. Jung, J. Hong, C.-H. Wang, D. S. Alessi, S. S. Lee, Y.-K. Park and E. E. Kwon, Environ. Sci. Technol., 2020, 54, 6329-6343.

67 R. Yao, J. E. Herrera, L. Chen and Y.-H. C. Chin, ACS Catal., 2020, 10, 6952-6968.

68 A. Bouzoubaa, A. Markovits, M. Calatayud and C. Minot, Surf. Sci., 2005, 583, 107-117.

69 P. Arnoldy, J. C. M. D. Jonge and J. A. Moulijn, 2002, 89, 4517-4526.

70 L. Cedeño Caero, A. R. Romero and J. Ramirez, Catal. Today, 2003, 78, 513-518.

71 A. Spojakina, E. Kraleva, K. Jiratova and L. Petrov, Appl. Catal. Gen., 2005, 288, 10-17. 
72 I. T. Ghampson, G. Pecchi, J. L. G. Fierro, A. Videla and N. Escalona, Appl. Catal. B Environ., 2017, 208, 60-74.

73 J. Mosrati, H. Atia, R. Eckelt, T. H. Vuong, J. Rabeah, M. Mhamdi and U. Armbruster, J. Catal., 2021, 395, 325-339.

74 R. B. Quincy, M. Houalla, A. Proctor and D. M. Hercules, J. Phys. Chem., 1990, 94, 1520-1526.

75 K. Hamraoui, S. Cristol, E. Payen and J.-F. Paul, J. Mol. Struct. THEOCHEM, 2009, 903, 73-82.

76 K. D. Chen, S. B. Xie, E. Iglesia and A. T. Bell, J. Catal., 2000, 189, 421-430.

77 K. Chen, S. Xie, A. T. Bell and E. Iglesia, J. Catal., 2001, 198, 232-242.

78 H. Hu and I. Wachs, J. Phys. Chem., 1995, 99, 10911-10922.

79 H. Liu, P. Cheung and E. Iglesia, J. Catal., 2003, 217, 222-232.

80 A. Christodoulakis, E. Heracleous, A. A. Lemonidou and S. Boghosian, J. Catal., 2006, 242, 16-25.

81 M. Høj, T. Kessler, P. Beato, A. D. Jensen and J.-D. Grunwaldt, Appl. Catal. Gen., 2014, 472, 29-38.

82 A. de Lucas, J. L. Valverde, L. Rodriguez, P. Sanchez and M. T. Garcia, Appl. Catal. Gen., 2000, 203, 81-90.

83 D. P. Debecker, B. Schimmoeller, M. Stoyanova, C. Poleunis, P. Bertrand, U. Rodemerck and E. M.

Gaigneaux, J. Catal., 2011, 277, 154-163.

84 K. Ding, A. Gulec, A. M. Johnson, T. L. Drake, W. Wu, Y. Lin, E. Weitz, L. D. Marks and P. C. Stair, ACS Catal., 2016, 6, 5740-5746.

85 M. Dieterle, G. Weinberg and G. Mestl, Phys. Chem. Chem. Phys., 2002, 4, 812-821.

86 K. V. R. Chary, T. Bhaskar, G. Kishan and K. R. Reddy, J. Phys. Chem. B, 2001, 105, 4392-4399.

87 S. K. Maity, M. S. Rana, S. K. Bej, J. Ancheyta, G. M. Dhar and T. Rao, Appl. Catal. -Gen., 2001, 205, 215-225.

88 D. Laudenschleger, H. Ruland and M. Muhler, Nat. Commun., 2020, 11, 3898.

89 C. Morterra, A. Chiorino, F. Boccuzzi and E. Fisicaro, Z. Für Phys. Chem., 1981, 124, 211-222.

90 Y. Ji and Y. Luo, J. Am. Chem. Soc., 2016, 138, 15896-15902.

91 S. Kattel, B. Yan, J. G. Chen and P. Liu, J. Catal., 2016, 343, 115-126. 